\title{
抑制後のファン効果
}

対象集団に連結させる特性が多ければステレオタイプへの接近可能性は低くなるのか?

$\bigcirc$ 大江 朋子 (OE Tomoko) ・ 繁栘 算男 (SHIGEMASU Kazuo)

(東京大学大学院総合文化研究科)

Key words: ステレオタイプ、抑制、ファン効果

ある思考を抑制した後には、その思考への接近可能性が過 剰に高まることがある。これはリバウンド効果として知られ る比較的頑健な現象であり（Wegner, 1994）、ステレオタイプ 的思考を抑制した場合にも生じる。しかし、常にステレオタ イプへの接近可能性が高まるわけではない (Gordijn et al., 2004; Monteith et al., 1998; Oe \& Oka, 2003)。抑制後にステレ オタイプへの接近可能性が高まらない理由としては、以下の 2 つの説明が考えられる。本研究では、どちらが妥当な説明 かを検証するために実験を行った。

反ステレオタイプ 反ステレオタイプ特性はステレオタ イプに反する特性であり、それが活性化されるほどステレオ タイプへの接近可能性は低くなる (Dijksterhuis \& Knippenberg, 1996）。実験参加者に反ステレオタイプ的な人物を想像させる と、統制条件に比べ、潜在連合課題でステレオタイプの影響 を受けにくいという結果も得られている（Blair et al., 2001）。 抑制時に反ステレオタイプ特性を活性化させれば、反ステレ オタイプ特性への接近可能性は高くなり、ステレオタイプへ の接近可能性は低減すると考えられる。

ファン効果 一つの対象に連結する概念の数が多いほど、 それぞれの概念は検索・想起されにくくなる (ファン効果 fan effect; Anderson, 1974)。ステレオタイプを抑制する場合にも、 一つの集団に対して多くの特性概念が活性化されれば、各特 性概念の検索に要する時間は長くなると考えられる。したが って、抑制時に反ステレオタイプ特性を活性化させたのであ れば、ステレオタイプ特性と反ステレオタイプ特性の接近可 能性はどちらも低くなるのである。

\section{方 法}

実験参加者 千葉県の 1 大学で心理学の概論授業を受講す る大学生 80 名。語彙決定課題の正答率が $80 \%$ 以下の参加者 を除外し、79名（男性 41 名、女性 38 名）を分析対象とした。

実験計画 想像課題（統制、ステレオタイプ活性化、連結 なし抑制、連結あり抑制） ×特性語（ステレオタイプ特性、 反ステレオタイプ特性、無関連特性)。特性語は被験者内要因。

手続き 実験参加者は記憶に関する実験であると告げら れ、1〜2名ごとに実験室に入り、コンピュータ上で想像課題 と語彙決定課題を順に行った。統制条件の参加者は、語彙決 定課題のみを行った。想像課題 1 人の高齢者男性の写真を見 ながら、5 分間でその人物について想像し記述する課題であ り、課題開始前に次のように条件を操作した。(1)ステレオタ イプ活性化: 多くの人がもつ高齢者イメージをもとに人物記 述をするように要求した。(2)連結あり抑制：高齢者ステレオ タイプの影響を受けないように注意してほしいという教示を することで抑制を促した。その後、写真の人物が反ステレオ タイプ特性（いつも積極的で迅速に行動し、いろいろな意味 で強い人だと認識されている）を現在有するものとすること で、反ステレオタイプ特性を高齢者表象に連結させて考えさ せた。(3)連結なし抑制：連結あり抑制と同一の抑制の教示を 行い、その後、写真の人物が反ステレオタイプ特性を若いこ ろに有していたとすることで、反ステレオタイプ特性が高齢 者表象に連結しないように促した。

語彙決定課題 概念への接近可能性を測定するため、語彙 決定課題を実施した。コンピュータ画面上に提示されたター
ゲットに意味があるかどうかをできるだけ速く正確に判断す る試行が繰り返され、ターゲットが提示されてから参加者の キー入力があるまでの時間が記録された。各単語への反応時 間が短いほど、各概念への接近可能性が高いとみなした。

ターゲットには単語と非単語が半数ずつ含まれており、こ れらを各ブロックで無作為順に提示した。単語には、高齢者 のステレオタイプ特性、反ステレオタイプ特性、ステレオタ イプ無関連特性をそれぞれ 6 単語提示した。

\section{結 果 と考 察}

対数変換後の反応時間を従属変数とし、想像課題（課題な し、ステレオタイプ活性化、連結なし抑制、連結あり抑制） と特性語（ステレオタイプ、反ステレオタイプ、ステレオタ イプ無関連）と参加者の性別を独立変数とした分散分析を行 った。その結果、特性の種類の主効果 $(F(2,142)=36.67, p$ $<.01)$ と想像課題 $\times$ 特性の交互作用効果 $(F(6,142)=6.76, p$ <.01）が有意となった（図 1)。他の効果はみられなかった。 特性語ごとに $t$ 検定を行うと、ステレオタイプ特性では、 ステレオタイプ活性化条件の反応時間が、課題なし条件 $(p$ $<.10)$ と連結あり抑制条件（ $p<.05 ）$ の反応時間よりも短か った。ステレオタイプの利用が、ステレオタイプ特性への接 近可能性を高めたことを意味する結果である。さらに、連結 なし抑制条件の反応時間は、課題なし条件 $(p<.05)$ と連結 あり抑制条件 $(p<.01)$ より短かった。これは、抑制後のス テレオタイプへの接近可能性が、連結なし条件では高まり、 連結あり条件では高まっていないことを示している。他の条 件間に有意な差はみられなかった。

反ステレオタイプ特性で、連結なし抑制条件の反応時間が、 課題なし条件 $(p<.05)$ と連結あり抑制条件 $(p<.05)$ の反 応時間よりも短かった。他の条件間では、いずれも有意な差 はみられなかった。連結なし抑制条件では、抑制時に反ステ レオタイプ特性が利用され、それらの特性への接近可能性が 高まったことが示された。さらに重要なことに、連結あり抑 制条件でも反ステレオタイプ特性が利用されたが、それらの 特性への接近可能性は高まっていない。この結果はファン効 果の説明を支持するものである。

ステレオタイプ無関連の特性では、いずれの条件間にも有 意差がみられないことを予測していたが、課題なし条件の反 応時間が、ステレオタイプ活性化条件と $(p<.10)$ と連結な し抑制条件 $(p<.10)$ の反応時間よりも長かった。課題なし 条件の参加者は入室後すぐに語彙決定課題を始めたため、実 験状況自体にまだ慣れていなかったのかもしれない。他の条 件間では、いずれも有意な差はみられなかった。

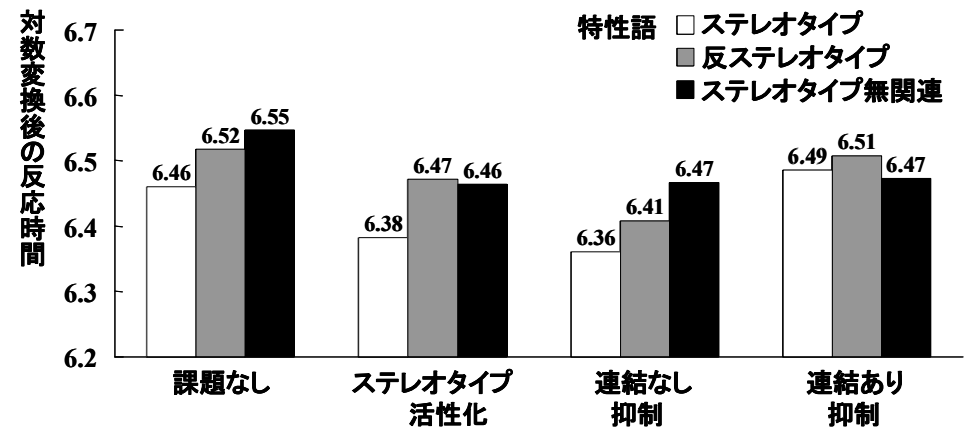

